\author{
V. Kravchenko ${ }^{1}$, V. Breslavets ${ }^{1}$, I. Yakovenko ${ }^{1}$, Qiu Jing Hui ${ }^{2}$ \\ ${ }^{1}$ National Technical University "Kharkiv Polytechnic Institute", Kharkiv, Ukraine \\ ${ }^{2}$ Harbin Institute of Technology, Harbin, China
}

\title{
EXTRANEOUS ELECTROMAGNETIC RADIATION IMPACT ON WAVEGUIDE CHARACTERISTICS OF A SEMICONDUCTOR SUPERLATTICE
}

\begin{abstract}
The subject matter is the mechanisms of emergence of instabilities in natural oscillations of semiconductor supertattices caused by their interaction with charged particle flows of extraneous electromagnetic radiation. The aim is calculating ratios to determine a degree of deviation of operating characteristics of semiconductor components from the norm, depending on the parameters of extraneous pulsed electromagnetic radiation. The objective is to model how currents that are induced with extraneous EMR interact with electrostatic oscillations of a semiconductor supertattice, using an implementation of (Cherenkov) resonance interaction of moving charges with electromagnetic oscillations under conditions where the phase velocity of the wave and the velocity of the charged particle are the same. The methods used: analytical methods for solving Maxwell's equations and medium equations in a framework of hydrodynamic approach. The following results are obtained. We have studied semiconductor components of electronic equipment (supertattices) being exposed to strong pulsed electromagnetic fields. The study was focused on the nature of changes in the working capacity of the components. We show that the effect of pulsed electromagnetic radiation is accompanied by an emergence of currents in the conductive hardware elements and an emergence of internal fields within them. One kind of reversible failures of semiconductor hardware elements is determined, based on interaction of extraneous radiation induced currents with the intrinsic fields of the supertattices of the hardware components. Similar failures occur under conditions of Cerenkov radiation (when the current is parallel to the structure boundary). It is shown that such interaction leads to energy losses in the induced currents spent to excitation of natural oscillations of the supertattice, i.e. to emergence of an oscillation generation mode that is characterized with a change in the volt-ampere characteristics of the hardware. Conclusion. The results obtained in this work can be used to evaluate the efficiency of active radio electronic devices (amplifiers, generators and converters of electromagnetic oscillations in the millimeter and sub-millimeter ranges) being exposed to extraneous pulsed electromagnetic fields. The comparative analysis of quantitative evaluations of reversible failures of semiconductor devices in dependence on the spatial configuration of the acting field (induced current parallel to the structure boundary) allows solving problems in optimizing the degree of distortion of the performance characteristics of these devices.
\end{abstract}

Keywords: electromagnetic radiation; semiconductor structures; surface oscillations; charged particles; vibration decrement.

\section{Introduction}

Most of the available theoretical and experimental studies of the impact electromagnetic radiation (EMR) has on radio equipment consider irreversible failures. (As you know, all types of failures that arise in electronic devices are usually divided into reversible and irreversible [1-4]). An irreversible failure mean complete loss of the device's functional characteristics. It occurs when the device performance changes beyond the permissible limits (in case of extraneous electromagnetic radiation, irreversible failures usually arise due to thermal breakdown of the components).

The mechanisms of irreversible failures that arise because of interaction of EMR induced currents and voltages with the processes characterizing functional purposes of the devices are usually modelled within the framework of the theory of circuits with distributed parameters. This approach allows evaluating working capacity criteria in general (for example, estimating the critical energy level characterizing a thermal breakdown),

At the same time, for reversible failures, consisting in a temporary loss of working capacity, using circuit theory does not allow determining the distortion of the output characteristics of radio devices. Therefore, most of the problems associated with determining the mechanisms of reversible failures resulting from the impact induced currents have on operability of radio devices, remain open.
This paper compensates to some extent the existing knowledge gap in this area of research on reversible failures. It studies how charged particle fluxes induced by EMR interact with wave processes in semiconductor structures of modern microwave electronics.

\section{Task solution}

The object of the study is a periodic structure consisting of semiconductor wafers (semiconductor superlattice). It is assumed that a flow of charged particles emerges in the structure because of EMR. The flow loses some of its energy spent on excitation of electromagnetic oscillations in the structure. The dispersion characteristics of the structure and the mechanisms of interaction between a flow of charged particles and electrostatic oscillations are investigated in this article. We have obtained equations for natural frequencies and determined the energy losses occurring in the currents because of excitation of EMR in millimeter and submillimeter ranges of electromagnetic waves.

Let a monoenergetic neutral flux of charged particles with density $n_{0}$ pass with constant velocity $v_{0}$ through a periodic structure (with period $q$ ) consisting of alternating plasma layers $d_{1}$ and $d_{2}$ that differ in dielectric constant concentrations of conduction electrons $N_{01}$ and $N_{02}$. Let us determine the spectrum and attenuation (increase) of electromagnetic oscillations of such a system. We select the reference system in such a way that $\mathrm{X}$ - and $\mathrm{Y}$-axes are parallel and $\mathrm{Z}$-axis is per- 
pendicular to the interface. Note that the energy a charged particle loses passing through a layered dielectric were first considered in [5].

To describe electromagnetic properties of a structure consisting of plasma layers, neglecting the delay effects, we use the following system of equations:

$$
\begin{aligned}
& \operatorname{rot} \vec{E}=0 ; \operatorname{div}\left[\varepsilon_{0}(z) \vec{E}=4 \pi e(N+n) ;\right. \\
& \frac{\partial N}{\partial t}+\operatorname{div}\left[N_{0}(z) \vec{u}\right]=0 ; m \frac{\partial \vec{u}}{\partial t}=e \vec{E} ; \\
& \frac{\partial n}{\partial t}+\operatorname{div}\left(n_{0} \vec{v}+\vec{v}_{0} n\right) ; m\left(\frac{\partial \vec{v}}{\partial t}+v_{0} \frac{\partial \vec{v}}{\partial z}\right)=e \vec{E} .
\end{aligned}
$$

Here $n(r, t), N(r, t), v(r, t), u(r, t)$ are the perturbed concentrations and velocities of the electrons of the beam and of the stationary plasma; $\varepsilon_{0}(z)$ and $N_{0}(z)$ are periodic functions that get values $\varepsilon_{01 ; 02}$ and $N_{01 ; 02}$ within the limits of $d=d_{1}+d_{2}$. The indices 1 and 2 mean that the quantities in the equations (4) relate to the layers with thickness indexes 1 and 2 correspondingly. In the following, we have to introduce a scalar potential $\phi(r, t) ;(\vec{E}=-\vec{\nabla} \phi)$. At the interface, the following conditions of continuity of potentials and total currents $J_{i}$ (displacement and conductivity) are satisfied:

$$
\phi_{1}(0)=\phi_{2}(0) ; \quad J_{1}(0)=J_{2}(0),
$$

where $J_{i}=\frac{\varepsilon_{0 i} \partial E_{i z}}{4 \pi \partial t}+e\left(N_{0 i} u_{i z}+n_{0} v_{i z}+v_{0} n_{i}\right)$

Taking into account space-charge waves (SCW) that emerge in the structure due to a moving particle flux, there is a need for additional boundary conditions. We define the conditions using continuous flows of charged particles and their impulses. These conditions have the following form:

$$
n_{1}(0)=n_{2}(0) ; \quad v_{1 z}(0)=v_{2 z}(0) .
$$

Using the property of translational symmetry $\phi(z+d)=\phi(z) \exp (i k d)$ (where $k$ is an arbitrary wave vector), one can represent the boundary conditions on the layer separating planes as follows:

$$
\begin{gathered}
\phi_{1}\left(d_{1}\right)=\phi_{2}\left(-d_{2}\right) \exp (i k d) ; J_{1}\left(d_{1}\right)=J_{2}\left(d_{2}\right) \exp (i k d) ;(4) \\
n_{1}\left(d_{1}\right)=n_{2}\left(-d_{2}\right) \exp (i k d) ; v_{1 z}\left(d_{1}\right)=v_{2 z}\left(-d_{2}\right) \exp (i k d) .
\end{gathered}
$$

With assumption that all the variables are exponentially dependent on the coordinates and time, it is easy to obtain a solution for the equations in each layer. Using boundary conditions (2) - (3), undefined constants can be eliminated and a dispersion equation can be obtained that relates the frequency, wave vectors $\omega, q_{x, y}, k$ and the parameters of the medium.

Consider a one-dimensional case: $q_{x} ; q_{y}=0$. The solution of the system of equations (1) in the i-th layer has the following form:

$$
\phi_{i}(z)=A_{i} z+B_{i}+\frac{4 \pi e^{2} v_{0}}{\varepsilon_{i}}\left[\frac{C_{i} \exp \left(i \lambda_{i} z\right)}{\left(\omega+v_{0} \lambda_{i}\right)^{2}}+\frac{F_{i} \exp \left(-i \lambda_{i} z\right)}{\left(\omega-v_{0} \lambda_{i}\right)^{2}}\right] \times
$$

$$
\begin{aligned}
& \times \exp \left(i\left(\omega / v_{0}\right) z\right) ; \\
E_{i}= & -A_{i}-\frac{4 \pi i e v_{0}}{\varepsilon_{i}}\left[\frac{C_{i} \exp \left(i \lambda_{i} z\right)}{\omega+v_{0} \lambda_{i}}+\frac{F_{i} \exp \left(-i \lambda_{i} z\right)}{\omega-v_{0} \lambda_{i}}\right] \times \\
& \times \exp \left(i\left(\omega / v_{0}\right) z\right) ; \\
n_{i}= & \left(C_{i} \exp \left(i \lambda_{i} z\right)+F_{i} \exp \left(-i \lambda_{i} z\right)\right) \cdot \exp \left(i\left(\omega / v_{0}\right) z\right) ; \\
v_{i}= & -\frac{4 \pi e^{2}}{m \lambda_{i} \varepsilon_{i}}\left[\frac{C_{i} \exp \left(i \lambda_{i} z\right)}{\omega+v_{0} \lambda_{i}}-\frac{F_{i} \exp \left(-i \lambda_{i} z\right)}{\omega-v_{0} \lambda_{i}}\right] \times \\
& \times \exp \left(i\left(\omega / v_{0}\right) z\right)+e A_{i} /(i m \omega) . \\
& \text { Here } \varepsilon_{i}=\varepsilon_{0 i}-\omega_{0 i}^{2} / \omega^{2} ; \lambda_{i}=\omega_{0} /\left(v_{0} \sqrt{\varepsilon_{i}}\right) ; \omega_{0 i} ; \omega_{0}-
\end{aligned}
$$

Langmuir frequencies of electrons of stationary plasma and $A, B, C . F$ beam are arbitrary constants. It is evident that the potential contains terms of various kinds. The first and the second terms represent a solution of Laplace equation $\partial^{2} \phi / \partial z^{2}=0$, the third and fourth terms are the potentials induced with the SCW. It is easy to verify that solutions $A_{i}=0$ are possible for the boundary conditions because in this case $J_{i}(z)$ identically vanishes, the concentration and velocity of the particles depend on constants $C, F$ and the boundary conditions for the potentials (3) and (4) allow determining $B_{1}, B_{2}$ through $C, F$. In this case, we can obtain the following dispersion equation from the boundary conditions:

$$
\begin{gathered}
\cos \left(\omega / v_{0}-k\right) d=\cos \lambda_{1} d_{1} \cos \lambda_{2} d_{2}- \\
-\left(\lambda_{1}^{2}+\lambda_{2}^{2}\right) /\left(2 \lambda_{1} \lambda_{2}\right) \cdot \sin \lambda_{1} d_{1} \sin \lambda_{2} d_{2} .
\end{gathered}
$$

This equation was first obtained in [6], where the possibility of emergence of unstable states was shown. At the same time, in [10], the natural vibrations that are related to the frequency dispersion of the dielectric permutation and exist in the structure in absence of a beam were not taken into account.

In a case of a small beam density $\lambda_{1} d_{1}<<1$; $\lambda_{2} d_{2}<<1$, equation (6) transforms to:

$$
\cos \left(\omega / v_{0}-k\right) d=1-\omega_{0}^{2} d^{2} /\left(2 v_{0}^{2} \varepsilon_{z z}\right),
$$

where $\varepsilon_{z z}(\omega)=d \varepsilon_{1} \varepsilon_{2} /\left(d_{1} \varepsilon_{2}+d_{2} \varepsilon_{1}\right)$ is a component of a permittivity tensor of a finely dispersed medium.

In the case of a weak spatial dispersion: $\omega d / v_{0}<<1 ; \quad k d<<1$ in equation (7), we get:

$$
\left(\omega / v_{0}-k\right)^{2}=\omega_{0}^{2} /\left(v_{0}^{2} \varepsilon_{z z}\right)
$$

The dispersion law of oscillations has the same form as in a homogeneous medium whose dielectric permittivity is equal to $\varepsilon_{z z}\left(\omega, d_{1}, d_{2}\right)$. From equation (8), in approximation of a low beam density, we get:

$$
\Delta \omega^{2}=\omega_{0}^{2} /\left(\varepsilon_{z z}\left(\omega=k v_{0}\right)\right) ; \Delta \omega<<v_{0} .
$$

In this case, the frequency of oscillations is determined by the flight time of a particle through the spatial period of the structure $\tau=d / v_{0}$. While $l$ is equal to the 
ratio of the flight time to the period of oscillations. The oscillations become unstable under condition of $\varepsilon_{z z}<0 \quad\left(\Delta \omega^{2}<0\right)$, i.e. the dielectric permittivity of at least one of the layers must have frequency dispersion and be negative. Let $\varepsilon_{2}>0, \varepsilon_{1}<0$. Then it follows from (8) - (9) that

$$
\Delta \omega^{3}=\omega_{0}^{2} \omega_{p 1} d_{1} /\left(2 \varepsilon_{01} d\right) .
$$

The instability increment

$$
\operatorname{Im} \Delta \omega=\frac{\sqrt{3}}{2}\left(\omega_{0}^{2} \omega_{p 1} d_{1} /\left(2 \varepsilon_{01} d\right)\right)^{1 / 3}
$$

where $\omega_{p 1}=\omega_{01} / \sqrt{\varepsilon_{01}}$.

If $\omega=k v_{0}$ then we have instability under conditions of Cherenkov's resonance with an increment that is $\left(d_{1} / d_{2}\right)^{1 / 3}$ times less than in a homogeneous plasma. In the case of $\omega_{p}=\left(2 \pi v_{0} / d\right) \cdot l$, the instability relates to Cerenkov's parametric radiation of a charged particle [7]. It follows from (8) that instability also arises when $\varepsilon_{z z}$ is a complex value and $\operatorname{Re} \varepsilon_{z z}>0$.

The studied model of the interaction between induced currents and oscillations in semiconductor components of electronic radio equipment is quite universal and allows considering a number of interesting particular cases in experiments to determine criteria of resistance to reversible failures.

\section{Analysis}

Table 1 contains numerical estimates of instability increments of intrinsic electromagnetic oscillations of semiconductor-layered structures caused by their interaction with charged particle fluxes induced by extraneous EMR. The results are provided for a number of semiconductor structures [7] being used in modern microwave electronics.

The amplitude of current is $J \approx 100 \mu \mathrm{A}$ and the rectangular pulse duration is $1 \mu \mathrm{s}$.

Table 1. Characteristics of MOS Structure

\begin{tabular}{|l|c|c|}
\hline \multicolumn{1}{|c|}{ MOS Structure } & \multicolumn{1}{c|}{$\begin{array}{c}\text { Concentration of carriers } n_{0},(\mathrm{~cm})^{-3} ; \\
\text { superlattice thickness } d,(\mathrm{~cm})\end{array}$} & $\begin{array}{c}\text { Instability increment } \\
\delta \omega,\left(\mathrm{s}^{-1}\right)\end{array}$ \\
\hline $\mathrm{Au}-\mathrm{Si}_{3} \mathrm{~N}_{4}-\mathrm{GaAs}$ & $n_{0}=5 \times 10^{14} d=3 \times 10^{-4}$ & $\delta \omega=2 \times 10^{11}$ \\
\hline $\mathrm{Au}-\mathrm{Al}_{2} \mathrm{O}_{3}-\mathrm{AlGaAL}$ & $n_{0}=1,3 \times 10^{15} d=2 \times 10^{-4}$ & $\delta \omega=4,7 \times 10^{11}$ \\
\hline $\mathrm{Au}-\mathrm{SiO}_{2}-\mathrm{CuInAs}$ & $n_{0}=3,6 \times 10^{14} d=9 \times 10^{-5}$ & $\delta \omega=5,2 \times 10^{11}$ \\
\hline $\mathrm{Au}-\mathrm{Si}_{3} \mathrm{~N}_{4}-\mathrm{AlGaAL}$ & $n_{0}=1,2 \times 10^{15} d=3 \times 10^{-3}$ & $\delta \omega=2,9 \times 10^{11}$ \\
\hline $\mathrm{Au}-\mathrm{Si}_{3} \mathrm{~N}_{4}-\mathrm{Si}$ & $n_{0}=3 \times 10^{15} d=1,6 \times 10^{-4}$ & $\delta \omega=3,2 \times 10^{11}$ \\
\hline $\mathrm{Au}-\mathrm{Al}_{3} \mathrm{O}_{2}-\mathrm{Si}$ & $n_{0}=3 \times 10^{15} d=3,6 \times 10^{-5}$ & $\delta \omega=2 \times 10^{11}$ \\
\hline $\mathrm{Au}-\mathrm{SiO}_{2}-\mathrm{Si}$ & $n_{0}=3 \times 10^{15} d=3 \times 10^{-4}$ & $\delta \omega=6,1 \times 10^{11}$ \\
\hline
\end{tabular}

\section{Conclusions}

A model is proposed here for interaction between extraneous EMR induced currents and electrostatic oscillations of a semiconductor superlattice basing on an implementation of resonance (Cherenkov) interaction between moving charges and electromagnetic oscillations under conditions of the phase velocity of the wave and the velocity of a charged particle being the same. Ratios are calculated that relate a value of the instability increment to the magnitude of the induced currents and such parameters of the MOS structures as free carrier concentration, dielectric constant and structure dimensions. The quantitative estimates show that the value of the radiation energy falls within the sensitivity range of modern receivers of submillimeter radiation.

\section{REFERENCES}

1. Averkov, Yu.O. and Yakovenko, V.M. (2009), "Transition radiation of a modulated electron beam crossing a wire screen", Radiophysics and Electronics, Vol. 14, No. 3, pp. 337-343.

2. Averkov, Yu.O. and Yakovenko, V.M. (2009), “'Excitation of surface electrostatic waves in semibounded layered superconductors by a nonrelativistic electron beam", ZhTF, Vol. 79, No. 5, pp. 87-94.

3. Vavriv, D.M., Suchkov, G.M., Vinogradov, V.V., Volkov, V.A., Kozhin R.V. and Alekseev, E.A. (2002), "Electromagneticacoustic thickness measurer for thin-walled tubes testing", Defektoskopiya, No. 10, pp. 7-13.

4. Sebko, V.P., Suchkov, G.M. and Alekseev, E.A. (2002), "Optimization of parameters of electromagnetic-acoustic (EMA) thickness measurers for thin articles testing”, Defektoskopiya, No. 12, pp. 21-28.

5. Averkov, Yu.O., Bass, F.G. and Yakovenko, V.M. (2009), "Excitation of surface excitons in semi-bounded solids by a nonrelativistic electron beam", FTT, No. 51 (1), pp. 57-64.

6. Kravchenko, V.I., Yakovenko, V.I., Yakovenko, I.V. and Losev, F.V. (2009), "Impact of extraneous factors on semiconductor components of electronic radio-devices", Vestnik_NTU "KhPI”, NTU "KhPI", Kharkiv, No. 11, pp. 62-69.

7. Beletsky, N.N., Khankina, S.I., Yakovenko, V.I. and Yakovenko, I.V. (2010), "Interaction between surface plasmons amd charged particle flows passing through the interface", ZhTF, Vol. 80, No. 4, pp. 120-125. 
8. Khankina, S.I., Yakovenko, V.I. and Yakovenko, I.V. (2011), "Electronic states on an uneven surface of a solid body surface", FNT, Vol. 37, No. 11, pp. 1148-1155.

9. Kravchenko, V.I., Korobko, A.I. and Yakovenko, I.V. (2014), "Influence of external electromagnetic factors on waveguide characteristics of semiconductor components of electronic devices", Vestnik NTU "KhPI", NTU "KhPI", Kharkiv, No. 21, pp. 79-84.

10. Kravchenko, V.I. and Yakovenko, I.V. (2014), "Mechanisms of failure of semiconductor components of electronic products under the influence of external electromagnetic radiation", Vestnik NTU "KhPI", NTU "KhPI", Kharkiv, No. 21, pp. 84-88.

Received (Надійшла) 23.02.2018

Accepted for publication (Прийнята до друку) 25.04.2018

\section{Вплив стороннього електромагнітного випромінювання на хвильові характеристики напівпровідникової решітки}

\section{В. І. Кравченко, В. С. Бреславець, І. В. Яковенко, Чу Цзинь Куй}

Предметом вивчення $є$ механізми виникнення нестійкостей власних коливань напівпровідникових надграток, обумовлених їх взаємодією з потоками заряджених частинок в умовах впливу зовнішнього електромагнітного випромінювання. Мета - отримання розрахункових співвідношень, які дозволяють визначати ступінь відхилення робочих характеристик напівпровідникових комплектуючих від норми в залежності від параметрів зовнішнього імпульсного електромагнітного випромінювання. Задача - отримання моделі взаємодії наведених зовнішнім електромагнітним випромінюванням струмів з електростатичними коливаннями напівпровідникової надгратки, заснованої на реалізації резонансної (черенковської) взаємодії рухомих зарядів і електромагнітних коливань в умовах, коли збігаються фазова швидкість хвилі i швидкість зарядженої частинки. Використовувані методи: аналітичні методи рішення рівнянь Максвелла і рівнянь середовища в рамках гідродинамічного підходу. Отримано наступні результати. Проведено дослідження функціонування напівпровідникових комплектуючих електрорадіовиробів (надгграток) в умовах впливу потужних імпульсних електромагнітних полів. Вивчено характер змін працездатності напівпровідникових комплектуючих елементної бази технічних засобів. Показано, що вплив імпульсного електромагнітного випромінювання супроводжується виникненням струмів в провідних елементах виробів і виникненням їх внутрішніх полів. Визначено один з типів оборотних відмов напівпровідникової елементної бази електрорадіовиробів, заснований на взаємодії струмів, наведених зовнішнім випромінюванням, 3 власними полями надгграток, що комплектують виріб. Подібні відмови реалізуються в умовах черенковського випромінювання (струм паралельний до кордонів структури). Показано, що дана взаємодія призводить до енергетичних втрат наведених струмів на збудження власних коливань надграток, тобто появі режиму генерації коливань, який характеризується зміною вольт-амперних характеристик радіовиробів. Висновки. Результати, отримані в роботі, можуть бути використані при оцінці працездатності активних радіоелектронних приладів (підсилювачів, генераторів і перетворювачів електромагнітних коливань міліметрового та субміліметрового діапазонів) в умовах впливу зовнішніх імпульсних електромагнітних полів. Проведений в роботі порівняльний аналіз кількісних оцінок оборотних відмов напівпровідникових приладів в залежності від просторової конфігурації поля, що впливає (наведений струм паралельний до кордонів структури), дозволяє вирішувати задачі оптимізації ступеня спотворення робочих характеристик даних приладів.

Ключов і слов а: електромагнітне випромінювання; напівпровідникові структури; поверхневі коливання; заряджені частинки; декремент коливань.

\section{Влияние стороннего электромагнитного излучения на волноводные характеристики полупроводниковой решетки}

В. И. Кравченко, В. С. Бреславец, И. В. Яковенко, Чу Цзинь Куй

Предметом изучения являются механизмы возникновения неустойчивостей собственных колебаний полупроводниковых сверхрешеток, обусловленных их взаимодействием с потоками заряженных частиц в условиях влияния внешнего электромагнитного излучения. Цель - получение расчетных соотношений, позволяющих определять степень отклонения рабочих характеристик полупроводниковых комплектующих от нормы в зависимости от параметров внешнего импульсного электромагнитного излучения. Задача - получение модели взаимодействия наведенных внешним электромагнитным излучением токов с электростатическими колебаниями полупроводниковой сверхрешетки, основанной на реализации резонансного (черенковского) взаимодействия движущихся зарядов и электромагнитных колебаний в условиях, когда совпадают фазовая скорость волны и скорость заряженной частицы. Используемые методы: аналитические методы решения уравнений Максвелла и уравнений среды в рамках гидродинамического подхода. Получены следующие результаты. Проведены исследования функционирования полупроводниковых комплектующих электрорадиоизделий (сверхрешеток) в условиях воздействия сильных импульсных электромагнитных полей. Изучен характер изменений работоспособности полупроводниковых комплектующих элементной базы технических средств. Показано, что влияние импульсного электромагнитного излучения сопровождается возникновением токов в проводящих элементах изделий и возникновением их внутренних полей. Определен один из типов обратимых отказов полупроводниковой элементной базы электрорадиоизделий, основанный на взаимодействии токов, наведенных внешним излучением, с собственными полями сверхрешеток, комплектующих изделие. Подобные отказы реализуются в условиях черенковского излучения (ток параллелен границе структуры). Показано, что данное взаимодействие приводит к энергетическим потерям наведенных токов на возбуждение собственных колебаний сверхрешеток, т.е. появлению режима генерации колебаний, который характеризуется изменением вольт-амперных характеристик радиоизделий. Выводы. Результаты, полученные в работе, могут быть использованы при оценке работоспособности активных радиоэлектронных приборов (усилителей, генераторов и преобразователей электромагнитных колебаний миллиметрового и субмиллиметрового диапазонов) в условиях воздействия внешних импульсных электромагнитных полей. Проведенный в работе сравнительный анализ количественных оценок обратимых отказов полупроводниковых приборов в зависимости от пространственной конфигурации воздействующего поля (наведенный ток параллелен границе структуры) позволяет решать задачи оптимизации степени искажения рабочих характеристик данных приборов.

Ключевые слова: электромагнитное излучение; полупроводниковые структуры; поверхностные колебания; заряженные частицы; декремент колебаний. 